\title{
The Changing Role of Customer Experience in the Age of Industry 4.0
}

\author{
Gábor Rekettye a, Gábor Rekettye Jr. ${ }^{b}$ \\ aniversity of Pécs, Hungary, \\ bInternational Business School Budapest, Hungary
}

\section{THE AIMS OF THE PAPER}

The fourth industrial revolution will result in a paradigm shift in the production and the marketing of products and services. The digitalization driven paradigm shift will make it possible to personalize the marketing tools, like pricing, distribution, communication, customer management, and customer experience. The aim of the paper is twofold: firstly to draw attention to the increased importance of customer experience and secondly to discuss how customer experience has changed due to the digitalized business environment.

\section{METHODOLOGY}

The conceptual study builds on a comprehensive literature review. The literature studied includes scientific papers describing how customer experience has developed and altered in different industries. The desk research also took into consideration the published finding of researches carried out by well-known international research agencies.

\section{MOST IMPORTANT RESULTS}

One of the most important results of the study is to find an appropriate definition of customer experience and to find its role among the managerial functions. Another result is the knitting of customer experience to the development of the consumer decision journey. Digitalization has completely changed the traditional funnel type of the customer decision journey, new touchpoints have appeared and gained importance. The paper discusses the role of customer experience management and elaborates on the process of how companies should prepare their activities in this field to enhance their competitiveness.

\section{RECOMMENDATIONS}

The study concludes that companies to stay competitive have to map the decision journey of their existing and potential customers. They have to explore the important contact point and have to provide them with authentic content and information. This is rather difficult in today's multichannel environment. The realtime information they need should be provided through the analytics of big data. While collecting this information they should take care not to hurt the privacy of customers.

Keywords: digitalization, customer experience, personalization, customer decision journey, touchpoints, ethical questions

Acknowledgements: The research was financed by the Higher Education Institutional Excellence Programme of the Ministry for Innovation and Technology in Hungary, within the framework of the 4th thematic programme „Enhancing the Role of Domestic Companies in the Reindustrialization of Hungary” of the University of Pécs.

DOI: 10.15170/MM.2020.54.01.02 


\section{INTRODUCTION}

There is an unanimous consort among scientists that, in the first decades of the twenty-first century, the world is moving towards a new industrial revolution called Industry 4.0. (Schwab 2017, Liao et al. 2017, Vaidya et al. 2018). There is also a common understanding that digitalization is the core driving force of the fourth industrial revolution. The fourth industrial revolution was also the leading topic at the World Economic Forum in Davos, 2016, with the title: Mastering the Fourth Industrial Revolution. The forum discussed both the positive and negative aspects of the fourth industrial revolution. As Schwab put it: ,There has never been a time of greater promise, or peril." Studying the relevant international literature, we may conclude that according to scientists, the fourth industrial revolution will fundamentally transform the global system of production, which means a paradigm shift in manufacturing. (Moavenzdeh 2015, Baur \& Wee 2015, Geissbauer et al. 2016, Zhong et al. 2017, Xu et al. 2018). The cyber-physical system of the new production will result in radical cost reduction, in better quality, in faster time to market and in more customized - even personalized - production.

Less attention is devoted by the literature, however, to the marketing effects of the fourth industrial revolution. This study concludes that the tools of the fourth industrial revolution, especially the analytics of big data and its rational use, may lead to a paradigm shift in marketing as well. The real-time availability of information about the customers will give sellers the possibility to personalize not only the products and services but also the other means of the marketing mix: distribution, pricing, and communications (Rekettye \& Rekettye Jr. 2019). Because of all of these developments, the role of customer experience will be increasingly important. Customer experience is a relatively new field of modern marketing, and its use is continuously changing and getting more sophisticated due to the advanced digitalization.

\section{THE NOTION AND THE ROLE OF CUSTOMER EXPERIENCE}

Numerous studies have been published about customer experience (CX or sometimes $\mathrm{CE}$ ) in marketing literature over the past decade. The reason why customer experience has become a buzzword in marketing is that customers interact with the companies and their products in many new touchpoints, which have emerged as a result of digitalization. The appearance of these new touchpoints makes it unavoidable for both disruptors and incumbent companies to deal with customer experience. The prevailing view is that successful companies apply an additional layer to the quality representing the essence of their products and to the attractiveness of the appearance thereof, and this extra layer is none other than customer experience, positive customer experience (Figure 1.).

Figure 1. The new construct of the product onion

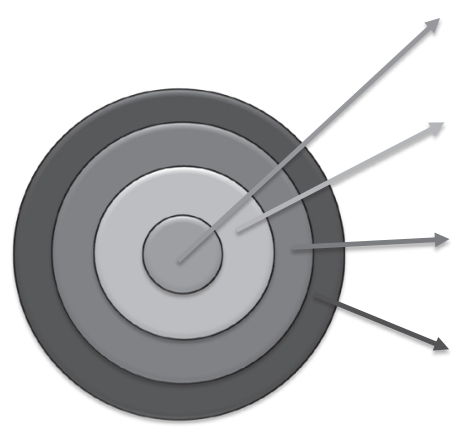

Core benefit: what customers want to use the product for.

Product quality: the satisfaction of customer needs the most functional way possible.

The attractiveness of the product: form and design, size, packaging, etc.

Customer experience expressed in all contacts between the company and its customers.

Source: Rekettye 2019, 81 
Market research reports prove that the importance of the role of customer experience has increased from the perspective of customers as well as the sellers of both consumer and industrial goods. A Salesforce's research (2018) made on a sample of around 7000 consumers and business buyers in the advanced countries states for example that

- $80 \%$ of customers say the experience a company provides is as valuable as its products/services;

- $\quad 67 \%$ of customers are willing to pay more for a great experience;

- $\quad 57 \%$ of the customers have stopped buying from a company because a competitor provided a better experience.

According to Acquia research (2018)

- $\quad 76 \%$ of consumers say, 'I am loyal to certain brands, but as soon as I have a bad experience with them, I am moving on.'
According to NICE in Contact research (2018)

- $\quad 89 \%$ of consumers are willing to buy more and

- $82 \%$ are ready to go out of their way to buy from companies that deliver exceptional customer experience.

Besides the above findings of customers' opinions, Kriss reported in an article of Harvard Business Review about the quantification of the impacts of customer experience (Kriss 2014). The study proved that in the case of transactional businesses customers who had the best experiences spend $140 \%$ more compared to those who had a poor experience. Similar results came out from their research in the case of subscription-based businesses.

Nevertheless, what does customer experience mean? Usertesting Agency asked seven industry experts about their view on customer experience (Table 1.).

\section{Table 1. Seven industry experts' opinions about CX}

\section{Blake Morgan, \\ Author, \\ Forbes columnist \\ John Koetsier, \\ Forbes Columnist, VP \\ of Insights at Singular \\ Dom Nicastro, \\ CMSWire}

Bruce Temkin,

Author, Customer

Experience Matters

blog

Janelle Estes,

Chief Insights Officer,

UserTesting

Douglas Karr,

CEO of DK New

Media and founder of

MarTech.Zone

Chanice Henry,

Editor-in-Chief of CX

Network

Source: Usertesting 2019
Customer experience considers everything the customer goes through-it's everything the customer touches, tastes, smells, hears, sees throughout the experience with the brand. What are they going to feel or think? It's being almost obsessive about the experience the customer has with the brand - the attitude of 'I want to be here,' rather than 'I have to be here.'

Customer experience means caring... But it does mean treating a customer like a person, not a unit. An individual, not a wallet with legs.

Do you know why experience is so important? Because customers no longer care about being marketed to. They can find out everything they need to know about a product on their own. It's how you treat them and help them after their initial purchase that will win you their loyalty.

The customer experience $(\mathrm{CX})$ movement has taught organizations that they need to think of the people (yes, real human beings), who are their customers. To better serve those human beings, many companies have moved from a reliance on limited periodic research studies to a continuous insights model that is built on "instrumenting" key experiences and driving action based on how customers think and feel.

Customer experience, or $\mathrm{CX}$, is how companies go to the market and engage people with not just a product but an emotional connection over the entire course of the relationship, to motivate and delight people.

Expectations of customer experience are made across the spectrum of every company that your customer is doing business with. If you hope to grow, improve retention, and build advocates, you need to surpass the CX of every brand they're working with.

As many industries enter an economy where consumers are becoming comfortable with switching brands, customer experience is now a vital tool in today's business strategies. Companies need to go beyond merely claiming to put customers in the driving seat and put them there. It's about breaking free from obsessive business-first, product-focused mindsets and maturing to live and breathe a customer-first culture. 
Table 1. proves that it is not easy to define CX. As Adam Richardson, the author of the first part of the series of articles on customer experience published in the Harvard Business Review, writes, "people have been grappling with a definition of customer experience for several years. Sometimes it's defined as digital experiences and interactions, such as on a website or a smartphone. In other cases, customer experience is focused on retail or customer service, or the speed at which problems are solved in a call center". According to him, customer experience is the "sum-totality of the emotions built up in the customer about the brand and the company throughout the entire arc of being a customer."

Lemon and Verhoef (2016), studying the vast literature of customer experience, concluded that it is a multidimensional construct that has rational, emotional, sensorial, and social factors.

"However, experience may relate to specific aspects of the offering, such as a brand or technology, and it consists of individual contracts between the firm and the customer at distinct points. Experience is built up through a collection of these touchpoints in multiple phases of customer decision process or purchase journey" (Lemon \& Verhoef 2016, 71).

The analysis of the history of marketing makes it is safe to state that customer experience has its antecedents both in theory and practice. Lemon and Verhof were going back until the 1960s and identified seven stages of marketing thinking, which have led from the customer buying behavior process model of the 1960 s to the customer engagement of the 2010s:

- $\quad$ Customer buying behavior process model: Understanding CX and customer decision making as a process (the 1960s -1970s);

- Customer satisfaction and loyalty: assessing and evaluating customer perceptions and attitudes about an experience (the 1970s);

- $\quad$ Service quality: identifying the specific context and elements of CX and mapping the customer journey (the 1980s);

- Relationship marketing: Broadening the scope of customer responses considered in the CX (the 1990s);

- Customer relationship management (CRM): linkage models to identify how specific elements of $\mathrm{CX}$ influence each other and business outcomes (the 2000s);

- Customer centricity and customer focus: focusing on the interdisciplinary and organizational challenges associated with suc- cessfully designing and managing $\mathrm{CX}$ (the 2000s - 2010s);

- Customer engagement: recognizing the customer's role in the experience (the 2010s)

The technological advancement of the last decades has changed, however, many aspects of the marketing thinking illustrated above. The amplitude of these changes has become radical through the development of information and communication technology (ICT). The Internet and the growing role of social media have altered consumer behavior and made lots of models about the buying behavior obsolete. Digitalization at the same time forced marketing scholars to build new models that could answer these radical changes.

One of these new models is the model of the 'service-dominant logic.' Looking at the definition of customer experience, we can realize that most of the customer experience can be traced back to the touchpoints with whom the customer gets in contact, notably the people involved in handling, manufacturing, and distributing the products. It gives a kind of "service character" to it all. Indeed, most of the examples cited by the literature are services. Nevertheless, customer experience is the key to success in the case of tangible goods as well. We are witnessing a kind of paradigm shift here. We must agree with Kenesei and Kolos (2017) who said that the new paradigm, the "service-dominant logic" (SDL) described by Vargo and Lusch (2004) should be understood in such a way that the tools of service marketing are to be introduced into the world of physical products. So perhaps one of the most critical tools in services marketing and customer experience are the appropriate people.

Customer experience is created as a result of the satisfaction of the buyer with the so-called touchpoints of the supplier. Some of these touchpoints are personal. It is an obvious objective of managers to make customers satisfied with the behavior of the company's employers, particularly frontline people easy to achieve. This is where human resource management (HRM) comes into play.

Another new model related to the above-mentioned one highlights the role of emotional intelligence. People with emotional intelligence should be hired for these positions and should be trained and empowered for these tasks, who possess the appropriate attitude towards the customers (Boxer \& Rekettye 2010). It is not easy to realize the vision of the management by the people working in the front lines. With mentioning the touchpoints, we arrived at the changing concept of the consumer decision journey. 


\section{CONSUMER DECISION JOURNEY}

Traditional marketing has taught that consumers take a particular journey before making their purchase decisions. This journey was illustrated with a funnel metaphor, where the number of potential brands gradually decreases. As Kotler and Keller describe in their 'five-stage model' (Kotler \& Keller 2006, 191), it starts with the stage of problem recognition, followed by the information search, evaluation of alternatives, and decision. The stage of decision is the purchase itself, followed by the post-purchase stage that shows the behavior of the customer, which can ideally manifest itself in loyalty, or even in evangelism (Kawasaki 2015). Representing the decision journey of consumers as a funnel implies that the initial list of brands considered worthy of attention by the consumers (initial consideration list) is gradually narrowed down in each step until only one remains at the point of purchase. Companies, through their marketing activities at the touchpoints, try to "push" their brands down the funnel.

Due to the radical changes of the last two decades, a lot of publications appeared about the findings of researches on how digitalization and other means of Industry 4.0 have altered the model of the customer decision journey. These researches were carried out in different fields of the economy and proved that the consumers' journeys are CX has different nature in different industries. Here are some publications about researches in different industries:

- $\quad$ Retail industry (Grewal et al. 2009, Roggeveen et al. 2019, Andajani 2020),

- Tourism (Yachin 2018),

- Business Schools (Nasermoadeli et al. 2013),

- Insurance (Hu \& Tracogna 2020),

- Automotive industry (Scherpen et al. 2018).

The research conducted by Court et al. (2009) aimed to find a generalized model for the decision journey in today's digital world. In their model, the whole decision-making process can be described more like a circular movement, in which the active evaluation phase follows the initial consideration list. For example, due to (or despite) the proliferation trend of products and media, the initial consideration list has become narrower than before; and in the following phases, brands can be subtracted from or new brands can be added to the list. The evaluation phase is followed by the closing, the purchase itself, and then the post-purchase phase. During this last phase, the consumer gains experience by using the product. He/she evaluates it and ideally enters the so-called loyalty loop (Figure 2).

Figure 2. The circular model of the consumer decision journey

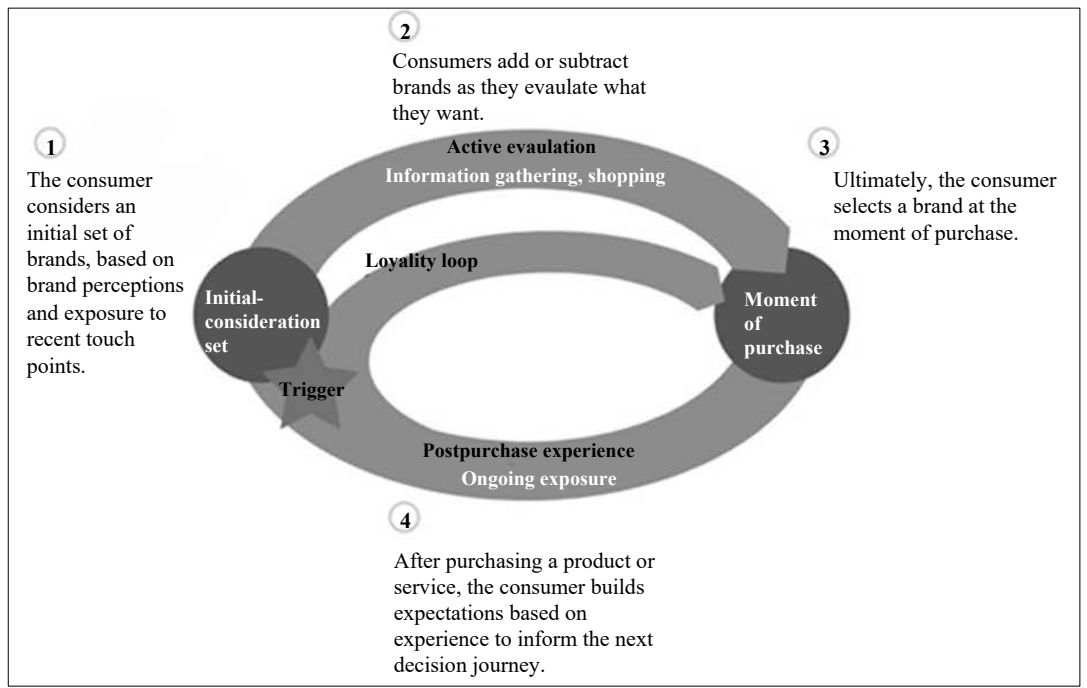

Source: Court et al. 2009, 5/13 
The research has provided several significant findings:

- Contrary to the funnel model, the initial consideration list, most of the time does not get narrowed down in the active evaluation phase; moreover, it gets expanded as a result of an intensive search for information. For example, the initial consideration list in the case of cars was typically 3.8 to which was added a further 2.2 during the intensive information search.

- The second important finding is that the touchpoints of the active evaluation phase were not dominated by the marketing activities of the suppliers, but rather by the customer-driven (,pull”) activity, particularly by online reviews, recommendations by friends and family members, as well as the interactions experienced in the shops. Traditional, supplier-driven marketing has a more important role in the creation of the initial consideration list, but its importance diminishes during the phases of active evaluation and final decision.

- The final decision is principally influenced by two factors: the personal interaction of the shop, the dealers and the agents, and the customer-driven marketing (word of mouth advertising, online search, offline search).

- The research has also revealed that there are two kinds of loyalty. Some of the customers are what we call active loyalists, who not only keep buying the same brand, but they also recommend it to others. The passive loyalists, on the other hand, are stuck with the same brand for convenience's sake or from fear of the misleading variety of choices of brands even though they might not be all too fond of their decisions.

\section{CUSTOMER RELATIONSHIP MANAGEMENT (CRM) VS. CUSTOMER EXPERIENCE MANAGEMENT (CEM)}

Since the beginning of the new millennium, we are witnessing the emergence of a new marketing theory: the customer relationship management (CRM). Companies invested a lot of money to create an efficient customer relationship management system to increase the quality of the relations with their key customers and, through this, to improve the value provided for their stakeholders (Agárdi - Gyulavári 2017). In most cases, customer relationship management could contribute to the improvement of value creation and could increase the share of loyal customers. In many cases, however, CRM just remained a database providing lots of information, sometimes too much to be able to handle them, but did not help to understand the customers themselves. Despite the considerable investments in CRM, many of them did not pay off. "According to a Gartner survey, about 70 percent of CRM projects resulted in either losses or not a bottom-line improvement in organization performance" (Foss et al. 2008, 69).

The need has emerged to find a system that can manage the totality of customer experience. CX is much more than just information about existing customers. It includes almost every side of the company's offer: the quality of the products, their performance and design, packaging, the convenience of their use, and of course, the quality of the customer contacts, including the quality of the online and offline marketing activity. This new system has been manifested in the customer experience management (CEM). CEM as a higher-order resource of cultural mindsets toward customer experiences (CEs), strategic directions for designing CEs, and firm capabilities for continually renewing CEs, with the goals of achieving and sustaining long-term customer loyalty (Frow \& Payne 2007, Schwager \& Meyer 2007, Homburg et al. 2017). There are inevitable overlapping between CRM and CEM. However, there are some significant differences between them, as explained below.

- The difference in their objectives: while CRM collects and distributes what the company knows about customers, CEM is focusing on what customers know and think about the company.

- There is a difference between when and where. While CRM monitors the transaction with customers and reports the information after the deal, CEM wants to be there at every interaction at the touchpoints.

- There is a difference between the users of the information: while CRM provided information is used mainly by those parts of the company which are in direct contact with customers (marketing, sales, and customer service), CEM information is used by all business and functional managers who can contribute to the creation of better experience with products and services. 
Customer experience management is a process that starts with mapping the consumers' decision journey to explore contact points between the company and its existing and potential customers. The phase of mapping is followed by the collection of the necessary real-time information, the dissemination among company executives, and the process is finalized by the implementation and the control (Figure 3.).

\section{Figure 3. Major steps in the process of customer experience management}

\begin{tabular}{|c|c|c|c|c|}
\hline Mapping & Analytics & Dissemination & Action & Control \\
\hline $\begin{array}{l}\text { - Mapping the } \\
\text { touchpoints } \\
\text { of the } \\
\text { consumer } \\
\text { decision } \\
\text { journey of the } \\
\text { given } \\
\text { industry }\end{array}$ & $\begin{array}{l}\text { - Collecting } \\
\text { real-time } \\
\text { information } \\
\text { about the } \\
\text { needs of } \\
\text { prospects on } \\
\text { these } \\
\text { touchpoints - } \\
\text { with the help } \\
\text { of Big-Data } \\
\text { analytics }\end{array}$ & $\begin{array}{l}\text { Distributing } \\
\text { the necessary } \\
\text { information } \\
\text { among all } \\
\text { company } \\
\text { personal, who } \\
\text { can } \\
\text { contribute to } \\
\text { the best } \\
\text { handling of } \\
\text { the } \\
\text { touchpoints }\end{array}$ & $\begin{array}{l}\text { Providing } \\
\text { autethentic } \\
\text { online and } \\
\text { offline } \\
\text { information, } \\
\text { content and } \\
\text { other forms } \\
\text { of customer } \\
\text { service on } \\
\text { these } \\
\text { touchpoints }\end{array}$ & $\begin{array}{l}\text { - Feedback } \\
\text { and } \\
\text { measuring the } \\
\text { results, } \\
\text { preparing for } \\
\text { modifications } \\
\text { if needed }\end{array}$ \\
\hline
\end{tabular}

Source: own construction

There are lots of models in the scientific and professional literature for mapping the customer decision journey. The task is rather complicated since most customers use a multichannel approach and even the same products may have different journeys. Wolny and Charoensuksai (2014) studied, for example, the decision journey of cosmetic products and concluded that customers' journey should be grouped in segments depending on the buying behavior of customers. In their research, they distinguished three segments, the impulsive journey, the balanced journey, and the considered journey.

\section{PERSONALIZATION OF CUS- TOMER EXPERIENCE - SOME ETHICAL CONSIDERATIONS}

One of the most important groups of factors influencing customer experience is knitted to sellers. Their communication towards their customers and other activities at different touchpoints have a significant effect on the consumers purchasing decisions. The researches mentioned earlier proved that the impact of sellers' activity at these touchpoints could be more successful if they are well-targeted or even personalized. In Acquia research, for example, $78 \%$ of the consumers said that they would be more loyal to a company or a brand that showed that they understood customers and knew what they were looking for. How customers see the ways they can be treated individually is presented in Figure 4. 


\section{Ways Brands Can Make Customers Feel Like An Individual $\because \because:^{\text {marketing }}$}

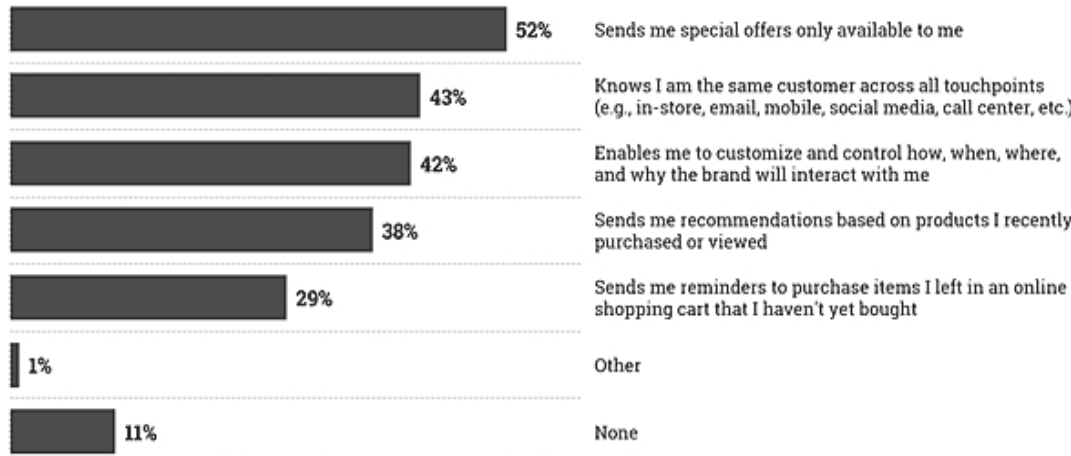

Published on MarketingCharts.com in April 2019| Data Source: RedPoint Global

Source: https://www.marketingcharts.com/customer-centric/personalization-customer-centric-108074? mc_cid=cd4255ca44\&mc_eid=3085ef12e5, Accessed April 13, 2019.

The technology for making the company's communication with existing customers and with prospects personalized is available. It is enough to mention the considerable progression in the analytics of big data, the AI (artificial intelligence), cloud computing, etc. One would think that the new technology should make the online experience with brands better. However, according to the Acquia survey, the truth is not so cut and dry. Even though marketers have invested a lot in marketing technology and want to continue it, 74 percent of them feel that technology has made it more challenging to deliver a personalized experience for the customers.

When talking about the use of personalized information, one barrier and one contradiction must be mentioned. There is a need to ensure to meet the data compliance standards, like GDPR. The contradiction is that, however, consumers prefer to get personalized treatment from the companies they do not like to give up their privacy. This contradiction is illustrated in Figure 5. Therefore, they hesitate to give their permission to use their data unless they see their direct benefit.

Figure 5. The contradiction between customers' expectations and their readiness to give access to their private information

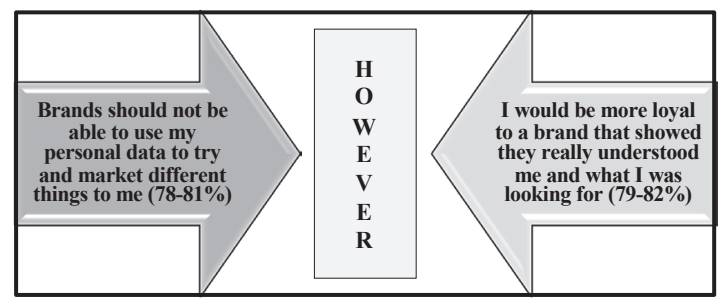

Source: Based on Acquia research

Note: The percentages figures in the brackets show the lowest and highest average country results obtained for the given question. 
So, companies need to find ways to convince customers that permitting to use their IDs is worthy and beneficial to them. Let us take the example of the Turkish loyalty program called Hopi. Hopi creates value for its customers and member merchants. Hopi personalizes its merchants' campaigns by taking advantage of big data and artificial intelligence. The unique artificial intelligence software behind Hopi matches the needs and expectations of its customers with the thousands of offers of its member merchants in the most appropriate way. Thus, Hopi's customers can follow and benefit from the most attractive campaigns and offers that fit their preferences and habits. Currently, $70 \%$ of Hopi customers voluntarily share their location information with Hopi (Yetkin 2019).

\section{CONCLUSIONS}

The study has proved that in the era of Industry 4.0 personalized customer experience is gaining in importance. Companies need to deal with it; otherwise, they will lose their competitiveness. To be successful in this field

- Companies must be present at the touchpoints generated by the customers. All the touchpoints for each product must be known, and the active loyalists must be continuously provided with appropriate and authentic content.

- It is important to ensure that customers, consumers are not to be disappointed at the personal touchpoints. It increases the importance of human resource management.

- One of the priorities is to understand the customer decision journey and make sure that the product is included in the initial consideration list, and after that to provide the potential customers with appropriate and personalized information during the active evaluation phase.

- Finally, by identifying the appropriate touchpoints, the company should ensure that the customers' post-purchase experience is positive as well, and they immediately enter into the loyalty loop during the repurchase.

The limitations of this conceptual study are twofold: the first limitation originates from the fact that it is based on desk research. While selecting the sources some important ones could be neglected. The second limitation comes from the wide-ranging nature of the topic. There was no place in this study to deal with all the important aspects of the field. For example, the study did not touch the topic of how the new methods for example, artificial intelligence - are accepted and disseminated by the different segments of the customers. These limitations show, at the same time, the possible directions for further researches. Besides dealing with all aspects of the topic, the findings of the desk research could be verified by field research. 


\section{REFERENCES}

Acquia (2018), Closing the Gap: Customer Experience Trends Report 2019, Retrieved from https://www.acquia.com/resources/ebooks/ closing-cx-gap-customer-experience-trends-report Downloaded: 2020.04.06

Agárdi I, Gyulavári, T. (2017), „CRM-Stratégiák a bank- és biztosítási szektorban" (CMR strategies in the banking and insurance industries), Vezetéstudomány, XlVIII(2), Doi: 10.14267/ Veztud.2017.02.04

Andajani, E. (2015), Understanding Customer Experience Management in Retailing, Procedia - Social and Behavioral Sciences. (211), 629633 DOI: 10.1016/j.sbspro.2015.11.082

Baur, C. and Wee, D. (2015), Manufacturing's next act. McKinsey\&Company, June 2015

Boxer, I and Rekettye G. (2010), "The influence of perceived emotional intelligence on the perceived service value and customer loyalty". Acta Oeconomica 60(3) 275-293 http://dx.doi. org/10.1556/aoecon.60.2010.3.3.

Court D, Elzinga, D., Mulder, S. and Vetvik O., J. (2009), "The consumer decision journey," McKinsey Quarterly, June

Foss, B., Stone, M. and Ekinc, Y (2008), "What makes for CRM system success - Or failure?" Journal of Database Marketing \& Customer Strategy Management, 15(2), 68-78 http:// dx.doi.org/10.1057/dbm.2008.5. Downloaded: 2020.04.06

Frow, P., Payne, A. (2007), "Towards the 'perfect' customer experience". Journal of Brand Management. 15 89-101 DOI:10.1057/palgrave. bm. 2550120

Geissbauer, R., Vedsø, J, and Schrauf, S. (2016), “A Strategist's Guide to Industry 4.0", STRATEGY + BUSINESS, Summer, 83

Grewal, D., Levy, M. \& Kumar, V. (2009), "Customer Experience Management in Retailing: An Organizing Framework". Journal of Retailing, $\quad 85$ 1-14 https://doi.org/10.1016/j.jretai.2009.01.001

Homburg, C., Jozić, D. and Kuehnl, C. (2017), "Customer experience management: toward implementing an evolving marketing concept". Journal of the Academy of Marketing Science, 45(3), 377-401 http://dx.doi.org/10.1007/ s11747-015-0460-7.

Hu, T. I., Tracogna, A. (2020), "Multichannel customer journeys and their determinants: Evidence from motor insurance", Journal of Retailing and Consumer Services, 54, https://doi. org/10.1016/j.jretconser.2019.102022.
Kawasaki, G. (2015), "The Art of Evangelism", Harvard Business Review, May

Kenesei Zs. and Kolos K. (2018), „Szolgáltatásmarketing - múlt vagy jövő?" (Services marketing - past or future?) Budapest Management Review, XLIX(1), 1-12 http://dx.doi. org/10.14267/veztud.2018.01.01.

Kotler, P, Keller, K. L. (2006), Marketing Management, Pearson

Kriss, P. (2014), "The Value of Customer Experience, Quantified", Harvard Business Review, August

Leeflang, P. S. H., Verhoef, P.C, Dahlström P., Freundt T. (2014), "Challenges and solutions for marketing in a digital era," European Management Journal, 32 1-12 http://dx.doi. org/10.1016/j.emj.2013.12.001.

Lemon, K. N. and Verhoef, P. C. (2016), "Understanding Customer Experience throughout the Customer Journey", Journal of Marketing, 80 (November) 69-96 http://dx.doi.org/10.1509/ jm.15.0420.

Liao Y., Deschamps F., de Freitas Rocha Loures, E., Pierin Ramos, L. F. (2017), Past, present and future of Industry 4.0 - a systematic literature review and research agenda proposal. International Journal of Production Research, DOI:10. 1080/00207543.2017.1308576

Moavenzadeh, J. (2015), The 4th Industrial Revolution: Reshaping the Future of Production. In: Nielsen The sustainability imperative - New insights in consumer expectations, October 2015, Nielsen

Nasermoadeli, A., Ling, K. C. \& Severi, E. (2013), "Exploring the Relationship between Social Environment and Customer Experience." Asian Social Sciences, 9(1), http://dx.doi.org/10.5539/ ass.v9n1p130.

NICE in Contact (2018), 2018 Customer Experience (CX) Transformation Benchmark Retrieved from https://www.niceincontact. com/call-center-resource-finder/2018-cx-transformation-benchmark-study Downloaded: 2020.04.06

Rekettye G. and Rekettye G. Jr. (2019), "The effects of the digital revoution on costs and prices," In: Saša Drezgić; Saša Žiković; Marko Tomljanović (eds.) Economics of Digital Transformation, University of Rijeka, Faculty of Economics and Business, 131-145. https://ssrn.com/ abstract $=3491767$ or http://dx.doi.org/10.2139/ ssrn.3491767 Downloaded: 2020.04.06

Rekettye, G. (2019), Value Creation 4.0 - Marketing Products in the $21^{\text {st }}$ Century, Transnational Press London 
Richardson, A. (2010), "Understanding Customer Experience", Harvard Business Review, (10)

Roggeveen, A. L., Grewal, D. \& Schweiger, E. B. (2019), The DAST Framework for Retail Atmospherics: The Impact of In- and Out-ofStore Retail Journey Touchpoints on the Customer Experience. Journal of Retailing, https:// doi.org/10.1016/j.jretai.2019.11.002.

Salesforce research (2018), State of the Connected Customers - Insights from $6700+$ consumers and business buyers on the intersection of experience, technology, and trust, Retrieved from https://www.salesforce.com/content/ dam/web/en_us/www/documents/e-books/ state-of-the-connected-customer-report-second-edition2018.pdf Downloaded: 2020.04.06

Schwab, K. (2017), The Fourth Industrial Revolution. New York: Penguin, Random House

Schwager, A. and Meyer, C. (2007), "Understanding Customer Experience", Harvard Business Review, (February), Article Reprint No. R0702G

Usertesting (2019), What is customer experience (CX)? 7 industry experts weigh in, July 30, 2019. Retrieved from https://www.usertesting. com/blog/what-is-cx/ Downloaded: 2020.04.06

Vaidya, S., Ambad, P, Bhosle, S. (2018), Industry 4.0 - A Glimpse. Procedia Manufacturing, 20 233-238. http://dx.doi.org/10.1016/j. promfg.2018.02.034.
Vargo S. L. and Lusch R. F. (2004), "Evolving to a new dominant logic for marketing". Journal of Marketing, 68 (January) 1-17 http://dx.doi. org/10.1509/jmkg.68.1.1.24036.

Wolny, J. \& Charoensuksai, N. (2014), "Mapping customer journeys in multichannel decision-making", Journal of Direct, Data and Digital Marketing Practice. 15 317-326. DOI:10.1057/dddmp.2014.24

Xu L. D., Xu, E. L. \& Li, L. (2018), "Industry 4.0: s.tate of the art and future trends, International Journal of Production Research, 56(8), 29412962 DOI: 10.1080/00207543.2018.1444806

Yachin, J. M. (2018), “The 'customer journey': Learning from customers in tourism experience encounters", Tourism Management Perspectives, 28, 201-210 https://doi.org/10.1016/j. tmp.2018.09.002.

Yetkin, A. M. (2019), How Can a Loyalty Programme Deliver Value to Customers? The Case of Hopi, In: Rekettye G. Value Creation $4.0-$ Marketing Products in the $21^{\text {st }}$ Century, Transnational Press London

Zhong, R. Y., Xu, X., Klotz, E., Newman, S. T. (2017), "Intelligent Manufacturing in the Context of Industry 4.0: A Review", Engineering. 3 616-630. http://dx.doi.org/10.1016/j. eng.2017.05.015.

Gábor Rekettye, DSc, PhD, Professor Emeritus rekettye.gabor@ktk.pte.hu Marketing at the Univeristy of Pécs

Gábor Rekettye Jr., PhD, Associate Professor grekettye@ibs-b.hu Marketing at the International Business School, Budapest 